Pendas : J urnal Ilmiah Pendidikan Dasar, ISSN Cetak : 2477-2143 ISSN Online : 2548-6950

Volume I Nomor 1, Desember 2016

\title{
IMPLEMENTASI MODEL PEMBELAJARAN TERPADU DALAM MENGEMBANGKAN KREATIVITAS ANAK SEKOLAH DASAR
}

\author{
Uum Murfiah ${ }^{1}$ \\ Aas Saraswati ${ }^{2}$ \\ 1,2 Universitas Pasundan \\ 1uummurfiah@unpas.ac.id \\ 2ceuaas@gmail.com
}

\begin{abstract}
The Implementation of integrated learning model in the development of children creativity at elementary school Pertiwi Bandung can be realized through three stages: (1) planning and preparation by the teacher, (2) the implementation phase, and (3) the assessment phase. In practice, the required media and learning resources that support integrated learning in order to develop the creativity of children. The research method used a qualitative approach to explore the meaning behind the events and words that are delivered by teachers as respondents. The results showed that the integrated learning was implemented in SD Pertiwi can develop children's creativity of elementary school.
\end{abstract}

Keywords: integrated learning, children's creativity, and primary school

\section{ABSTRAK}

Penerapan model pembelajaran terpadu dalam pengembangan kreativitas anak sekolah dasar SD Pertiwi Bandung dapat diwujudkan melalui tiga tahap, yaitu (1) perencanaan dan persiapan oleh guru, (2) tahap pelaksanaan, dan (3) tahap penilaian. Dalam pelaksanaannya, media yang diperlukan dan sumber belajar yang suport pembelajaran terpadu dalam rangka mengembangkan kreativitas anak. Metode penelitian menggunakan pendekatan kualitatif untuk mengeksplorasi makna di balik peristiwa dan kata-kata yang disampaikan oleh guru sebagai responden. Hasil penelitian menunjukkan bahwa pembelajaran terpadu dilaksanakan di SD Pertiwi dapat mengembangkan kreativitas anak-anak

Kata kunci: pembelajaran terpadu, kreativitas anak-anak, dan sekolah dasar.

\section{A. Pendahuluan}

Kebijakan kurikulum 2013 oleh pemerintah pusat melalui Kemendikbud memperoleh dukungan dalam pengimplementasiannya dari Dinas Pendidikan kota Bandung. Dengan diberlakukannya kurikulum 2013, menuntut adanya perubahan proses be- lajar mengajar. Pembelajaran di SD memiliki konsekuensi terhadap perubahan model pembelajaran yang selama ini cenderung tradisional hanya berpusat pada guru menjadi pembelajaran aktif dan kreatif pada siswa (student active learning). Salah satu model pembelajaran yang sesuai 
dengan penerapan kurikulum 2013 adalah pembelajaran terpadu.

Model pembelajaran terpadu ini bertolak dan dikembangkan dari kurikulum yang sudah terpadu (integrated curriculum). Namun, dalam pendidikan di Indonesia, biasanya kurikulum itu sudah dikembangkan ke dalam berbagai mata pelajaran yang terpisah satu dengan lainnya. Mengingat hal itu, maka hal pertama yang perlu mendapat perhatian guru dalam merancang pembelajaran terpadu di SD, yaitu ketelitian dalam mengidentifikasi dan menetapkan kompetensi dasar dan indikator pada setiap mata pelajaran yang akan dipadukan. Hal ini bukan pekerjaan mudah, sebab guru harus memahami betul kandungan isi dari masing-masing kompetensi dasar dan indikator tersebut sebelum dilakukan penggabungan. Keuntungan dalam pelaksanaannya pembelajaran terpadu pada tingkat SD yaitu dengan adanya penerapan sistem guru kelas, dimana dengan pengalamannya mengajarkan seluruh mata pelajaran, guru bisa lebih cepat melihat keterhubungan kompetensi dasar dan indikator antar mata pelajaran. (Udin S. Saud \& Novi Resmini, 2006:71).

Model pembelajaran terpadu ini pada hakikatnya merupakan suatu pendekatan pembelajaran yang memungkinkan peserta didik baik secara individual maupun kelompok aktif men cari, menggali dan menemukan konsep serta prinsip secara holistik dan autentik (Depdikbud, 1996:3). Pembelajaran ini merupakan model yang mencoba memadukan beberapa pokok bahasan (Beane, 1995 dalam Puskur, 2007:1).

Melalui pembelajaran terpadu, peserta didik dapat memperoleh pengalaman langsung sehingga dapat menambah kekuatan untuk menerima, menyimpan, dan menerapkan konsep yang telah dipelajarinya. Dengan demi kian, peserta didik terlatih untuk dapat menemukan sendiri berbagai konsep yang dipelajari secara menyeluruh, bermakna, autentik dan aktif (Trianto, 2014:7).

Peran guru dalam pembelajaran terpadu amat penting dalam mengembangkan kreativitas peserta didik sehingga mereka dapat menemukan sen diri berbagai konsep yang dipelajari secara menyeluruh, bermakna, autentik dan aktif. Hal ini karena guru pada jenjang pendidikan dasar memainkan peran dalam membimbing, mengarahkan, dan memfasilitasi serta memotivasi anak untuk kreatif dalam belajar. 
Pendas : J urnal Ilmiah Pendidikan Dasar, ISSN Cetak : 2477-2143 ISSN Online : 2548-6950

Volume I Nomor 1, Desember 2016

Mengingat posisi guru yang amat penting seperti itu, guru harus berperan bijaksana jangan sampai aturan-aturan yang diterapkan atau memberikan pekerjaan rumah yang dapat melemahkan kreativitas anak. Disamping itu guru harus dapat memilih dan memanfaatkan setiap kesem patan belajar untuk mengembangkan kreativitas anak. Dalam kesempatan apa saja baik di dalam ruangan maupun di luar rungan kelas guru dapat mengajak anak untuk mengembangkan kreativitasnya (Suratno, 2005:17).

Menerapkan pembelajaran terpadu di sekolah dasar (SD) relatif baru dalam implementasi kurikulum 2013. Penerapan pembelajaran terpadu di SD belum banyak dilakukan oleh guru. Kondisi ini menarik untuk dilakukan penelitian karena implementasi model pembelajaran terpadu di SD belum ba nyak dilakukan oleh peneliti lain. Di samping itu pula, penelitian dengan tema model pembelajaran terpadu di lapangan ini akan menambah wawasan peneliti dalam mengembangkan teori atau konsep dalam mata kuliah pembelajaran terpadu yang peneliti menjadi salah seorang pengampunya.

\section{Rumusan Masalah} salah di atas, maka dapat dirumuskan masalah penelitian sebagai berikut:

a. Bagaimanakah persiapan yang dila kukan guru dalam mengimplementasi model pembelajaran terpadu di SD Pertiwi Kota Bandung?

b. Bagaimanakah pelaksanaan pembelajaran terpadu di SD Pertiwi Kota Bandung?

c. Kendala apa saja yang dihadapi gu ru dalam mengimplementasikan mo del pembelajaran terpadu di SD Pertiwi Kota Bandung?

d. Bagaimanakah pengembangan kreativitas anak Sekolah Dasar melalui pembelajaran terpadu oleh guru di SD Pertiwi Kota Bandung?

\section{Tujuan Penelitian}

Berdasarkan rumusan masalah di atas, maka penelitian ini bertujuan untuk:

a. Mendeskripsikan persiapan yang dilakukan guru dalam implementasi model pembelajaran terpadu di SD Pertiwi Kota Bandung.

b. Mendeskripsikan pelaksanaan pem belajaran terpadu di SD Pertiwi Kota Bandung.

c. Mendeskripsikan kendala-kendala apakah yang dihadapi guru dalam mengimplementasikan model pem- 
Pendas : J urnal Ilmiah Pendidikan Dasar, ISSN Cetak : 2477-2143 ISSN Online : 2548-6950

Volume I Nomor 1, Desember 2016

belajaran terpadu di SD Pertiwi Kota Bandung.

d. Mendeskripsikan pengembangan kreativitas anak Sekolah Dasar melalui pembelajaran terpadu oleh guru di SD Pertiwi Kota Bandung.

\section{B. Landasan Teori}

\section{Kreativitas Anak Sekolah Dasar}

Pengembangan kreativitas anak sekolah dasar di Indonesia masih belum banyak dilakukan oleh guru. Hal ini bisa dipahami karena guru SD belum banyak yang menerapkan metode pembelajaran bervariasi. Guru masih menggunakan metode tradisional berupa ceramah dan tanya jawab. Guru juga masih senang memberikan tugas kepada siswa berupa pekerjaan rumah (PR) yang membuat anak merasa jenuh dengan mengerjakan tugas tersebut karena seringkali tidak diperiksa sehingga tidak ada umpan balik kepada siswa. Di sisi lain sebagian guru masih lemah dalam mengembangkan alat peraga pembelajaran. Alat peraga pembelajaran di sekolah dasar belum dijadikan media dalam kegiatan pembelajaran.

Kreativitas merupakan suatu aktivitas imajinatif yang menggambarkan kecerdikan dari pikiran yang berdaya untuk menghasilkan suatu pro- duk dan atau untuk menyelesaikan suatu persoalan dengan caranya sendiri (Suratno, 2005: 24). Kreativitas sangat erat dengan imajinasi (Elliot, 1975). Sedangkan Craft (2003) menyebutkan kreativitas sebagai hasil dari pikiran yang berdaya sekaligus dapat menyelesaikan persoalan. Lebih jauh Degraff dan Lawrence (Suyoto, 2003) menyatakan bahwa kreativitas adalah suatu aktivitas yang bertujuan, menghasilkan produk yang bernilai, jasa atau ide baru. Dengan demikian, individu yang kreatif adalah individu yang pikirannya berdaya (imajinatif), ditandai rasa keingintahuan yang tinggi (Craft, 2003).

Berdasarkan hasil penelitian Samples (2002) berkeyakinan bahwa orang yang kreatif adalah orang yang tetap mempertahankan kemampuan sejak masa kanak-kanak untuk menerima apa yang mereka pahami dan juga apa yang mereka tidak pahami. Orang yang kreatif terlihat dapat memasuki hal-hal yang telah mereka tetapi juga tidak asing dalam hal-hal yang belum diketahuinya. Orang yang kreatif tidak berarti mereka tidak menghormati pengetahuan konvensional, tetapi orang yang kreatif juga tidak terlalu mengagumi pengetahuan konvensional yang telah ada. 
Pendas : J urnal Ilmiah Pendidikan Dasar, ISSN Cetak : 2477-2143 ISSN Online : 2548-6950

Volume I Nomor 1, Desember 2016

Menurut Rhoders (dalam Munandar, 1999) menyimpulkan bahwa kreativitas dapat dilihat dari empat aspek, yaitu (1) kondisi pribadi (person), (2) proses (process), (3) dorongan (press) lingkungan, dan (4) produk yang dihasilkan.

Menurut Suratno (2005:39-40) menguraikan keempat aspek kreativitas. Kreativitas sesungguhnya merupakan keunikan individu dalam berinteraksi dengan lingkungannya. Dari ungkapan individu atau orang yang unik inilah diharapkan muncul gagasan atau ide baru, dan pada akhirnya dapat diciptakan sesuatu produk baru yang inovatif atau belum pernah ada sebelumnya. Masing-masing anak me miliki bakat dan kreativitas yang berbeda, oleh sebab itu orang tua dan guru dapat menghargai keunikan pribadi masing-masing anak. Demikian juga hendaknya jangan memaksa anak untuk melakukan hal yang sama.

Lebih lanjut Suratno (2005:42) bahwa kreativitas dapat diwujudkan jika didukung oleh lingkungan dan kemauan dari dari dalam dirinya yang kuat. Terdapat dua faktor pendukung seseorang, yaitu kemauan dari dalam (motivasi intrinsik) dan kemauan yang disebabkan karena dorongan dari luar (motivasi ekstrinsik).
Kreativitas tidak muncul secara instan. Kreativitas tumbuh kembang melalui suatu proses kreatif pada diri seseorang. Untuk mengembangkan kreativitas dengan memberikan keleluasaan kepada anak untuk melakukan berbagai kegiatan eksperimen dalam rangka mewujudkan atau meng ekspresikan dirinya secara kreatif.

Kondisi pribadi dan lingkungan yang kondusif dalam pengembangan kreativitas anak akan melahirkan suatu produk kreatif. Orang tua dan guru memiliki peran penting dalam mengembangkan kreativitas anak. Dengan demikian orang tua dan guru harus mampu menemukan bakat dan ciri-ciri pribadi anak. Bakat dan ciri kreatif yang dimiliki anak tersebut hendaknya dikembangkan dengan cara memberikan dorongan kepada anak untuk lebih kreatif. (Suratno, 2005:43).

Berbagai pandangan dan konsep di atas semakin memperkuat bahwa kreativitas harus dibangun sejak anakanak. Untuk mengembangkan kreativitas anak, maka guru pun harus kreatif dalam mengembangkan potensi kreatif anak-anak.

2. Model Pembelajaran Terpadu di Sekolah Dasar

a. Konsep Pembelajaran Terpadu 
Integrated berarti hasil dari beberapa perpaduan, apapun bentuk yang dipadukan menghasilkan sebuah wajah baru. Misalnya perpaduan warna merah dipadukan dengan warna kuning akan menghasilkan warna orange, warna biru dipadukan dengan warna kuning akan menghasilkan warna hijau, warna merah dipadukan dengan warna biru akan menghasilkan warna ungu. Warna orange, warna hijau dan warna ungu merupakan perpaduan beberapa warna inilah yang disebut dengan integrated.

Pembelajaran terpadu memberikan sebuah pemahaman dari beberapa materi menghasilkan sebuah wajah baru yang disebut tema, istilah tema yang dikembangkan saat ini terutama dalam pendekatan kurikulum 2013 merupakan perpaduan dari beberapa mata pelajaran. Konsep tema dari perpaduan sebenarnya sudah lama dikembangkan, hanya saja di Indonesia baru dikembangkannya. Bahkan pada kurikulum 2013 istilah yang lebih mencuat adalah tematik integratif untuk kelas I-VI pada jenjang sekolah dasar/madrasah ibtidaiyah (SD/MI).

Pendekatan tematik terpadu ini memiliki elemen perubahan adanya peningkatan dan keseimbangan soft skill dan hard skill yang meliputi kom- petensi sikap, keterampilan, dan pengetahuan. Kompetensi yang semula diturunkan dari mata pelajaran berubah menjadi mata pelajaran dikembangkan dari kompetensi. Kompetensi yang dikembangkan adalah tematik terpadu dalam semua mata pelajaran.

Pendekatan multidisiplin merupakan pendekatan yang dikembangkan dalam kurikulum 2013, terutama dalam pendekatan yang dikembangkan dalam kurikulum sekolah dasar/ madrasah ibtidaiyah (SD/MI), sebuah pendekatan tematik terpadu dari beberapa mata pelajaran, namun materi yang dikembangkan disusun seimbang mencakup kompetensi sikap, pengetahuan, dan keterampilan.

Pembelajaran terpadu dapat dike mas dengan tema atau topik tentang suatu wacana yang dibahas dari berbagai sudut pandang atau disiplin keilmuan yang mudah dipahami atau dikenal peserta didik. Dalam pembelajaran terpadu, suatu konsep atau tema dibahas dari berbagai aspek bidang kajian. Misalnya dalam bidang kajian IPA tentang tema lingkungan dapat dibahas dari sudut makhluk hidup dan proses kehidupan (biologi), energi, dan perubahannya (fisika), materi dan sifatnya (kimia). Pembahasan tema juga dimungkinkan hanya dari aspek 
Pendas : J urnal Ilmiah Pendidikan Dasar, ISSN Cetak : 2477-2143 ISSN Online : 2548-6950 Volume I Nomor 1, Desember 2016

makhluk hidup dan proses kehidupan dan energi dan perubahannya atau materi dan sifatnya dan makhluk hidup dan proses kehidupan atau energi dan perubahannya dan materi dan sifatnya saja. Dengan demikian, melalui pembelajaran terpadu ini beberapa konsep yang relevan untuk dijadikan tema tidak perlu dibahas berulang kali dalam bidang kajian yang berbeda, sehingga penggunaan waktu untuk pembahasannya lebih efisien dan pencapaian tujuan pembelajaran juga diharapkan akan lebih efektif (Trianto, 2014:7).

Pembelajaran terpadu sangat sederhana jika diterapkan dalam sekolah dasar/madrasah ibtidaiyah (SD/ MI), dalam materi yang dikembangkan atau mata pelajaran yang dikembangkan memerlukan pendekatan yang terpadu sebagai acuan dasar untuk membentuk sebuah tema, pada sekolah dasar/ madrasah ibtidaiyah memungkinkannya dengan pendekatan tematik tersebut. Bahkan, kompetensi inti kelas I menyeimbangkan kompetensi sikap, keterampilan dan pengetahuan. Standar kompetensi lulusan pada ranah sikap pribadi yang beriman, berakhlak mulia, percaya diri, dan bertanggung jawab dalam berinteraksi efektif dengan lingkungan sosial, alam sekitar serta dunia dan peradabannya dengan cara menerima, menjalankan, menghargai, menghayati, dan mengamalkan.

Standar kompetensi lulusan ranah keterampilan memiliki pribadi yang berkemampuan pikir dan tindak yang efektif dan kreatif dalam ranah abstrak dan konkret dengan cara mengamati, menanya, mencoba, mengolah, menyaji, menalar, dan mencipta. Sementara standar kompetensi lulusan ranah pengetahuan, pribadi yang menguasai ilmu pengetahuan, teknologi, seni, budaya dan berwawasan kemanusiaan, kebangsaan, kenegaraan, dan peradaban dengan cara mengetahui, memahami, menerapkan, menganalisa, dan mengevaluasi.

Pendekatan yang digunakan untuk mengintegrasikan kompetensi dasar dari berbagai mata pelajaran yaitu intradisipliner, interdisipliner, multidisipliner, dan transdisipliner. Integrasi intradisipliner dilakukan dengan cara mengintegrasikan dimensi sikap, pengetahuan, dan keterampilan menjadi satu kesatuan yang utuh di setiap mata pelajaran. Integrasi interdisipliner dilakukan dengan menggabungkan kompetensi dasar pada beberapa mata pelajaran agar terkait satu dengan yang lainnya, sehingga dapat 
saling memperkuat, menghindari terjadinya tumpang tindih, dan menjaga keselarasan pembelajaran. Integrasi multidisipliner dilakukan tanpa menggabungkan kompetensi setiap mata pelajaran sehingga setiap mata pelajaran masih memiliki kompetensi dasarnya sendiri. Integrasi transdisipliner dilakukan dengan mengaitkan berbagai mata pelajaran yang ada dengan permasalahan-permasalahan yang dijumpai di sekitarnya sehingga pembelajaran menjadi kontekstual (Lampiran Permendibud Nomor 57 Tahun 2014 tentang Kurikulum 2013 SD/MI).

Forgarty (dalam Isjoni, 2007:133) menyatakan bahwa pembelajaran terpadu sebagai konsep dapat pula dikatakan sebagai pendekatan belajar mengajar yang melibatkan berbagai bidang studi untuk memberikan pengalaman yang bermakna bagi anak. Dikatakan bermakna karena dalam pembelajaran terpadu anak akan memahami konsep-konsep yang mereka pelajari melalui pengalaman langsung dan menghubungkannya dengan konsep lain yang sudah mereka miliki.

Menurut Joni (dalam Trianto, 2014:56) menyatakan bahwa pembelajaran terpadu merupakan suatu sistem pembelajaran yang memungkinkan siswa, baik secara individual maupun kelompok, aktif mencari, menggali dan menemukan konsep ser ta prinsip keilmuan secara holistik, bermakna dan otentik. Pembelajaran terpadu akan terjadi apabila peristiwaperistiwa otentik atau eksplorasi topik /tema menjadi pengendali di dalam kegiatan pembelajaran, dengan berpartisipasi di dalam eksplorasi tema/ peristiwa tersebut siswa belajar sekaligus proses dan isi beberapa mata pelajaran secara serempak.

Menurut Hadisubroto (dalam Trianto, 2014:56) menyatakan bahwa pembelajaran terpadu adalah pembelajaran yang diawali dengan suatu pokok bahasan atau tema tertentu yang dikaitkan dengan pokok bahasan lain, konsep tertentu dikaitkan dengan konsep lain, yang dilakukan secara spontan atau direncanakan baik dalam satu bidang studi atau lebih, dan dengan belajar anak, maka pembelajaran menjadi bermakna.

Fokus pembelajaran bermakna sesuai dengan pandangan bahwa belajar adalah mengkonstruksi pengetahuan, yang di dalamnya siswa memahami pengalaman-pengalaman me reka. Pembelajaran bermakna dipandang sebagai tujuan pendidikan yang penting yang mensyaratkan pembelajaran tidak sekedar menyampaikan 
pengetahuan faktual dan juga mensyaratkan pertanyaan - pertanyaan asesmen yang menuntut siswa bukan sekedar mengingat atau mengenali pengetahuan faktual (Anderson dan Krathwol, 2010:98).

Sejalan dengan pandangan ini, Ausabel (dalam Sundayana, 2014:9) melalui teori pembelajaran bermakna bahwa learning takes place in the human organism through a meaningful process of relating new events or items to already existing cognitive consepts or propositions. Teori ini menunjukkan bahwa pembelajaran bagi peserta didik akan bermakna bila apa yang dipelajari oleh mereka berhubungan dengan apa yang diketahui dan dialaminya.

Pembelajaran yang memberikan sebuah makna kehidupan jika faktafakta yang ditemukan di lapangan dapat dengan mudah diatasi, problem solving dalam kehidupan menjadi sebuah acuan dan dijadikan sebagai sebuah pengalaman belajar yang dapat diterapkan didalam fakta-faktanya tersebut, pembelajaran yang diterima tidaklah merasa sia-sia, tetapi ada kebermaknaan yang diterima dalam proses menerima pengetahuan akibat langsung atau tidak menjadi bermakna bagi penerima pengetahuan tersebut.

Pembelajaran terpadu bukan lagi sebuah pembelajaran yang sulit diterapkan oleh setiap guru dalam memberikan pengajarannya kepada anak didiknya, pembelajaran terpadu tentunya melihat materi secara utuh bukan lagi secara parsial sehingga adanya gambaran yang besar dalam menerima materi. Pembelajaran terpadu memberikan kepada peserta didik untuk menggali apa yang belum diketahui dan apa yang sudah diketahui dalam menerima materi yang disampaikan dari gurunya.

Pembelajaran terpadu ini memberikan rangsangan kepada peserta didik untuk bertanya atau mengobservasi, atau menalar sebab akibat yang mungkin ditimbulkannya dari materi yang diterimanya, atau juga melakukan sebuah pendekatan ilmiah yang sederhana untuk mengembangkannya secara mandiri apa-apa yang menjadi rasa penasarannya dalam menggali apa-apa yang belum diketahuinya tersebut atau juga mempertajam pengetahuan yang sudah diketahuinya.

Model pembelajaran mengacu pada pendekatan pembelajaran yang akan digunakan, termasuk di dalamnya tujuan-tujuan pengajaran, tahap- 
Pendas : J urnal Ilmiah Pendidikan Dasar, ISSN Cetak : 2477-2143 ISSN Online : 2548-6950

Volume I Nomor 1, Desember 2016

tahap kegiatan pembelajaran, lingkungan pembelajaran, dan pengelolaan kelas (Arends, 1997:7). Sejalan dengan pendapat Prabowo (2000:6) bahwa pada dasarnya langkah-langkah pembelajaran terpadu mengikuti tahap-tahap yang dilalui dalam setiap model pembelajaran yang meliputi tiga tahap yaitu perencanaan, tahap pelaksanaan, dan tahap evaluasi. Berkaitan dengan itu maka sintaks model pembelajaran terpadu dapat direduksi dari berbagai model pembelajaran seperti model pembelajaran langsung (direct instruction), model pembelajaran kooperatif (cooperatif learning), maupun model pembelajaran berdasarkan masalah (problem based instruction).

Pembelajaran terpadu dikembangkan dengan landasan pemikiran progresivisme, konstruktivisme, Developmentally Practice (DAP), landasan normatif dan landasan praktis (Depdikbud,1996:5). Aliran progresivisme menyatakan bahwa pembelajaran seharusnya berlangsung secara alami, tidak artifisial. Pembelajaran di sekolah tidak seperti dalam dunia nyata sehingga tidak memberikan makna kepada kebanyakan siswa.

Pembelajaran terpadu juga dikembangkan menurut paham konstruktivisme yang menyatakan bahwa pengetahuan dibentuk sendiri oleh individu dan pengalaman merupakan kunci utama dari belajar bermakna. Belajar bermakna tidak akan terwujud hanya mendengarkan ceramah atau membaca buku tentang pengalaman orang lain. mengalami sendiri merupakan kunci kebermaknaan.

Prinsip utama yang dikembangkan dalam pembelajaran terpadu adalah Developmentally Appropriate Practice (DAP). Dalam DAP ini dinyatakan bahwa pembelajaran harus disesuaikan dengan perkembangan usia dan individu yang meliputi perkembangan kognisi, emosi, minat, dan bakat siswa.

Menurut Fogarty (1999) dalam Udin Saud dan Resmini (2006:133) bahwa terdapat sepuluh model pembelajaran terpadu ,yaitu: (1) fragmented, (2) connected, (3) nested, (4) sequenced, (5) shared, (6) webbed, (7) threaded, (8) integrated, immersed, (10) networked. Dari kesepuluh model yang dikemukakan tersebut, setidaknya ada tiga model yang cocok diterapkan di Indonesia, yaitu: model jaring laba-laba (webbing), model keterhubungan (connected), dan model keterpaduan (integrated). Dalam penerapannya sedikitnya ada empat hal yang perlu diperhati- 
Pendas : J urnal Ilmiah Pendidikan Dasar, ISSN Cetak : 2477-2143 ISSN Online : 2548-6950

Volume I Nomor 1, Desember 2016

kan, yaitu: (1) menentukan tujuan, (2) menentukan materi/media, (3) menyusun skenario KBM, dan (4) menentukan evaluasi.

Pembelajaran terpadu dalam implementasi pembelajaran di SD masih dianggap suatu model pembelajaran baru. Pembelajaran terpadu pada dasarnya merupakan suatu pendekatan yang melibatkan beberapa mata pelajaran secara terintegrasi untuk memberikan pengalaman yang bermakna kepada siswa. Sebagai suatu model pembelajaran, dalam penerapannya di SD memerlukan persiapan yang lebih kompleks dibandingkan dengan pembelajaran dalam satu mata pelajaran tertentu. Oleh karena itu, guru atau tim guru atau tim guru perlu melakukan perancangan pembelajaran agar siswa memiliki pengalaman belajar yang bermakna. Dalam menanamkan konsep pengetahuan dan keterampilan, siswa tidak perlu di drill, tetapi diarahkan untuk belajar melalui pengalaman langsung (direct experience) dan menghubungkannya dengan konsep-konsep lain yang sudah dipahami, sehingga sesuai dengan kebutuhan pelaksanaan pembelajaran terpadu (Udin S Saud, dkk, 2006: 131).

\section{Metodologi}

Penelitian ini menerapkan pendekatan kualitatif. Peneliti menjadi human instrumen (Satori, D. \& Komariah (2009).,dalam Sugiono (2016). Artinya peneliti menjadi alat utama untuk mengumpulkan data di sekolah. dasar pengumpulan data dilakukan melalui observasi dan wawancara dengan instrumen pendukung berupa alat rekam, camera, dan catatan dalam buku agenda penelitian. Responden dalam penelitian ini adalah guru wali kelas yang menerapkan pembelajaran terpadu. Data yang sudah diperoleh dianalisis melalui triangulasi data dan member cek kemudian dimaknai agar memberikan arti yang sesuai dengan tujuan penelitian ini.

\section{Hasil dan Pembahasan}

\section{Persiapan Guru dalam Implemen-} tasi Model Pembelajaran Terpadu

Pembelajaran terpadu di SDN Pertiwi Kota Bandung pada tataran implementasinya dimulai dengan langkah persiapan. Persiapan pem-belajaran terpadu merupakan awal yang penting bagi guru sebelum melaksanakan pembelajaran terpadu. Persiapan ini penting dilakukan oleh guru karena akan menentukan arah yang akan dilakukan oleh guru dalam 
Pendas : J urnal Ilmiah Pendidikan Dasar, ISSN Cetak : 2477-2143 ISSN Online : 2548-6950

Volume I Nomor 1, Desember 2016

pelaksanaan pembelajaran terpadu. Seorang guru kelas III menuturkan bahwa dalam persiapan pembelajaran terpadu yang ia lakukan adalah dengan menyiapkan diantaranya adalah rencana pelaksanaan pembelajaran (RPP), menyiapkan agenda harian guru meliputi penyusunan standar kompetensi dasar, tema, materi, tujuan pembelajaran, merumuskan indikator hasil belajar, serta media yang akan diterapkan dalam pelaksanaan pembelajaran. Lebih lanjut guru tersebut menyampaikan sebagai berikut:

Persiapan yang ia lakukan diantaranya menyiapkan RPP. Masingmasing guru ada agenda harian merupakan panduan ia dalam mengajar yang memuat tentang standar kompetensi dasar, tema, dan materi pembelajaran. Tujuan pembelajaran terpadu yang akan diberikan kepada siswa disesuaikan dengan tema dan materi. Tujuan dibuat setiap hari sesuai dengan tema yang akan disampaikan hari ini. Tujuan disesuaikan dengan tema dan materi yang akan disampaikan kepada peserta didik. Penyusunan materi disesuaikan dengan buku panduan atau buku paket.

Hal ini sejalan dengan pendapat Hadisubroto (2000:21) bahwa dalam merancang pembelajaran terpadu ada empat hal yang perlu diperhatikan oleh guru, yaitu (1) menentukan tujuan, (2) menetukan materi/media, (3) menyusun skenario KBM, dan (4) menentukan evaluasi. Sedangkan menurut Prabowo (2000) persiapan perencanaan pembelajaran terpadu secara khusus dapat dibuat sendiri meliputi penentuan kompetensi dasar dan menentukan indikator dan hasil belajar.

Menurut Trianto (2010:64-65) Tahap persiapan ini lebih dikenal dengan tahap perencanaan yang meliputi langkah-langkah perencanaan pembelajaran yaitu: (a) menentukan jenis mata pelajaran dan jenis keterampilan yang akan dipadukan. Karakteristik mata pelajaran menjadi pijakan untuk kegiatan awal ini. Seperti contoh diberikan oleh Forgaty (1991:28) untuk jenis mata pelajaran sosial dan bahasa dapat dipadukan dengan keterampilan berpikir (thinking skill) dengan keterampilan sosial (social skill). Sedangkan untuk mata pelajaran sains dan matematika dapat dipadukan keterampilan berpikir dan keterampilan mengorganisir (thinking skill dan organizing skill)., (b) memilih kajian materi, standar kompetensi, kompetensi dasar dan indikator. Langkah ini akan mengarahkan guru untuk 
menentukan sub keterampilan dari masing-masing keterampilan yang dapat diintegrasikan dalam suatu unit pembelajaran., (c) menentukan sub keterampilan yang dipadukan. Secara umum keterampilan-keterampilan yang harus dikuasai meliputi: keterampilan berpikir, keterampilan sosial dan keterampilan mengorganisir., (d) merumuskan indikator hasil belajar. Berdasarkan kompetensi dasar dan subketerampilan yang telah dipilih kemudian dirumuskan indikator. Setiap indikator dirumuskan berdasarkan kaidah penulisan yang meliputi: audience, behaviour, condition, dan degree., (e) menentukan langkahlangkah pembelajaran. Langkah ini diperlukan sebagai strategi guru untuk mengintegrasikan setiap subketerampilan yang telah dipilih pada setiap langkah pembelajaran.

\section{Pelaksanaan Pembelajaran Ter- padu}

Pelaksanaan pembelajaran terpadu mengacu pada persiapan dan perencanaan yang telah disipkan oleh guru. Dalam pelaksanaan pembelajaran terpadu membutuhkan kesiapan mental, emosional dan pemahaman yang mendalam terhadap tujuan yang ingin dicapai dalam setiap pembela- jaran. Berkaitan dengan pengembangan materi yang dilakukan oleh guru dapat disampaikan bahwa:

"Dalam pelaksanaannya materi dikaitkan dengan materi berikutnya. Materi yang disampaikan berdekatan bisa saja diberikan pada pertemuan yang sebelumnya. Jika materi habis bisa diberikan latihan-latihan. Guru hanya menggunakan buku paket atau panduan saja. Guru seharusnya banyak menggunakan referensi agar bertambah wawasannya. Media pembelajaran yang ada disekitar sekolah atau lingkungan sekolah. Media yang ada digunakan seperti infokus. Media yang digunakan di lingkungan sekolah adalah balong. Anak-anak di bawa ke balong untuk menjelaskan misalnya untuk menjelaskan tsunami. Pembelajaran agar menyenangkan. Pembelajaran IPS anakanak di bawa ke pasar. Pasar yang dekat dengan sekolah dijelaskan. Siswa merasa senang karena anak belajar sambil bermain. Siswa langsung menyerap informasi dengan mudah dan merasa senang."

Pernyataan guru tersebut memberikan pemahaman bahwa guru 
Pendas : J urnal Ilmiah Pendidikan Dasar, ISSN Cetak : 2477-2143 ISSN Online : 2548-6950

Volume I Nomor 1, Desember 2016

hendaknya kreatif dalam pembelajaran. Guru tidak hanya menjadi sumber belajar, tetapi menjadi fasilitator dalam pembelajaran. Sedangkan agar siswa dapat menyenangi pembelajaran perlu dikaitkan dengan lingkungan yang dapat menambah wawasan siswa dalam memahami pembelajaran yang nyata di masyarakat.

Dalam Depdiknas (1996:6) bahwa prinsip-prinsip utama dalam pelaksanaan pembelajaran terpadu, meliputi: pertama, guru hendaknya tidak menjadi single actor yang mendominasi dalam kegiatan pembelajaran. Peran guru sebagai fasilitator dalam pembelajaran terpadu memungkinkan siswa menjadi pembelajar mandiri; kedua, pemberian tanggungjawab individu dan kelompok harus jelas dalam setiap tugas yang menuntut adanya kerjasama kelompok; dan ketiga, guru perlu akomodatif terhadap ide-ide yang terkandung sama sekali tidak terpikirkan dalam proses perencanaan.

Hal ini dikuatkan dengan pernyataan guru bahwa:

"Tanggungjawab dalam melaksanakan tugas kelompok menuntut adanya kerjasama kelompok dalam penyelesaiannya. Dalam kerja kelompok tersebut menun- tut keaktifan dari setiap individu agar kerja kelompok dapat diselesaikan dengan baik. Sedangkan tugas guru menkondisikan kelompok agar bekerja kompak dan memberikan sinopsisnya."

Hal ini ditegaskan oleh Depdiknas (2008) tidak ada model pembelajaran tunggal yang cocok untuk suatu topik dalm pembelajaran terpadu. Artinya dalam satu tatap muka dipadukan beberapa model pembelajaran.

\section{Kendala-Kendala dalam Imple- mentasi Pembelajaran Terpadu}

Pembelajaran terpadu yang dilaksanakan di SD seringkali menemui kesulitan bahkan kendala dari internal guru sendiri maupun dari aspek eksternal. Kendala yang bersifat internal dari guru seringkali muncul berupa rasa malas, jenuh dan turunnya motivasi dalam mengajar. Hal ini sesuai dengan apa yang disampaikan oleh seorang guru bahwa:

"Kendala yang kadang saya rasakan adalah adanya rasa malas dan jenuh dalam mengajar. Dari pribadi guru kadang muncul perasaan malas dan jenuh itu manakala dihadapkan pada kon- 
Pendas : J urnal Ilmiah Pendidikan Dasar, ISSN Cetak : 2477-2143 ISSN Online : 2548-6950

Volume I Nomor 1, Desember 2016

disi yang rutinitas di sekolah. Ada pula kendala dari aspek luar seperti kurangnya media yang dapat digunakan untuk mendukung pembelajaran."

Rasa malas dan jenuh yang kadangkala muncul pada diri guru dapat diatasi dengan kegiatan yang sifatnya baru dan menantang. Kegiatan seperti temu kolegial, diskusi dalam KKG dan MGMP, rekreasi bersama, studi banding, mengikuti seminar, pelatihan untuk pengembangan kompetensi guru, dan bahkan studi lanjut. Kegiatan-kegiatan tersebut dapat diprogramkan oleh sekolah dalam upaya meningkatkan profesionalisme guru dan kompetensi guru di SD.

Aspek dari luar guru yang menjadi kendala dalam pembelajaran terpadu di SD yaitu kurangnya media pembelajaran yang relevan dengan materi yang akan disampaikan. Media pembelajaran di SD dapat menggunakan lingkungan sekolah yang sesuai dengan tema pembelajaran. Namun media pembelajaran yang menggunakan lingkungan sekolah atau sekitar sekolah belum banyak diterapkan guru. Media pembelajaran yang diterapkan oleh guru dalam pembelajaran sangat membantu siswa dalam memahami substansi pembelajaran.
Menurut Hosnan (2014) bahwa berdasarkan jenisnya, media terbagi menjadi media cetak, elektronik, dan multimedia. Media pembelajaran memiliki karakteristik menurut karakteristik yang berbeda pula, seperti media transportasi, media audio, media slide (film bingkai suara), media video, media CD multimedia interaktif, dan media internet.

\section{Pengembangan Kreativitas Anak dalam Pembelajaran Terpadu}

Pembelajaran terpadu di SD apabila diterapkan dengan persiapan dan perencanaan yang matang oleh guru akan memiliki pengaruh yang positif terhadap siswa. Salah satu pengaruh positif yang muncul pada diri anak adalah tumbuhnya kreativitas anak. Kreativitas anak bisa ditingkatkan dalam proses pembelajaran yang kreatif dan inovatif dengan menggunakan media pembelajaran yang menimbulkan rasa senang pada anak. Kreativitas anak juga dipengaruhi oleh minat dan bakat anak. Minat dan bakat ini apabila dapat digali akan melahirkan suatu kratifitas anak.

"Minat dan bakat anak bisa dijadikan langkah dalam pengembangan kreativitas. Sebenarnya anak memiliki minat dan 
Pendas : J urnal Ilmiah Pendidikan Dasar, ISSN Cetak : 2477-2143 ISSN Online : 2548-6950

Volume I Nomor 1, Desember 2016

bakat yang berbeda-beda. $\mathrm{Na}$ mun anak kadang-kadang merasa malu untuk tampil di ajang perlombaan tertentu, padahal ia memiliki minat dan kemampuan untuk ajang tersebut. Misalnya di SD ini ada anak yang memiliki kreativitas dalam menggambar dengan imajinasinya yang bagus. Anak tersebut tidak mau diikutkan dalam suatu perlombaan karena merasa malu dan belum adaptasi dengan lingkungan. Disinilah peran guru untuk memotivasi dan mengembangkan kreativitas anak yang memiliki minat dan bakat tersebut." (Guru SD Pertiwi).

Hosnan (2014:21) mengemukakan paling sedikit ada empat dasar pembentuk daya kreativitas seseorang (disebut CORE), yaitu:

a. Unsur pertama (C-curiosity) mengacu pada makna keingintahuan sebagai dasar untuk menimbulkan kreatif. Rasa ingin tahu mendorong orang untuk menyelidiki sesuatu yang baru, mencari cara untuk mengerjakan sesuatu dengan lebih baik, mengendalikan dorongan mencipta ataupun bereksperimen.

b. Unsur kedua (O-opennes) adalah olah keterbukaan, merupakan da- sar vital dalam pengembangan daya kreatif, seseorang tidak akan memiliki daya kreatif apabila hanya mau menerima keyakinan yang sudah baku, sehingga tidak akan merasa tertantang untuk memperluas cakrawala pengetahuan dan wawasannya.

c. Unsur ketiga (R-risk) adalah resiko, yaitu keberanian untuk mengambil resiko terhadap pengadopsian gagasan, ide, ataupun hal-hal baru. Kreativitas baru muncul apabila terdapat keberanian menanggung resiko dengan penolakan terhadap kemapanan ataupun rutinitas yang dihadapi sehari-hari.

d. Unsur keempat (E-energy) mengacu pada pengertian energi sebagai pendorong kerja dan pemacu hasrat. Tanpa adanya energi mental dan fisik, gagasan ataupun ide-ide kreatif tidak akan berlangsung. Dengan energi yang besar seseorang akan bergairah mengerjakan sesuatu dan semakin kreatif.

Mengembangkan kreativitas anak dalam pembelajaran terpadu bisa menggunakan pendekatan yang terpadu pula. Disisi lain guru bisa melibatkan unsur teman sebaya, orang tua dan masyarakat sekitar. Pada sisi teman sebaya pengembangan krea- 
tivitas bisa dilakukan dengan pemetaan minat dan bakat anak. Dengan mengetahui minat dan bakat anak yang sama akan membentuk suatu komunitas belajar anak untuk saling berdiskusi, bekerjasama, dan membantu dalam melahirkan suatu kreativitas. Unsur orang tua memiliki peran agar adanya kerjasama antara guru, anak, dan orang tua dalam pengembangan kreativitas anak. Guru membuat catatan tentang perkembangan kreativitas anak kepada orang tua agar orang tua dapat memfasilitasi anak di lingkungan keluarganya. Dengan adanya komunikasi dan interaksi dengan orang tua tentang perkembangan kreativitas anak diharapkan kreativitas anak semakin berkembang. Adapun aspek lingkungan dan masyarakat bisa menjadi media untuk mengembangkan kreativitas anak. Unsur lingkungan dan masyarakat bisa menjadi media dan inspirasi dalam pengembangan kreativitas anak. Anak akan memperoleh imajinasi dan informasi yang luas dari lingkungan dan masyarakat jika diarahkan oleh gurunya.

Dalam penuturan Guru bahwa:

"Media yang digunakan untuk mengembangkan kreativitas anak dalam materi kesenian yaitu dengan memanfaatkan barang bekas untuk membuat perkusi, koreografi dengan iringan musik yang sederhana. Dalam bidang sains, misalnya tentang tsunami dengan media kolam yang ada di sekolah. Membuat benda dari kertas yang bisa mengapung di atas air dan bergerak karena tertiup angin untuk memberikan materi tentang gaya derak benda."

Menurut Rhoders (dalam Munandar, 1999) menyimpulkan bahwa kreativitas dapat dilihat dari empat aspek, yaitu: (1) kondisi pribadi (person), (2) proses (process), (3) dorongan (press) lingkungan, dan (4) produk yang dihasilkan.

Peran guru dalam mengembangkan kreativitas anak adalah dengan memotivasi siswa. Motivasi dari guru dalam pengembangan kreativitas anak ini menjadi bagian penting dalam pembelajaran terpadu. Sebaliknya lemahnya motivasi dari guru membuat anak lemah juga dalam kreativitasnya.

Hal ini ditegaskan dengan pendapat guru bahwa:

"Memotivasi siswa untuk mengembangkan kreativitas penting agar anak menjadi percaya diri. Motivasi yang diberikan kepada 
siswa ada yang berupa oral atau langsung, adapula melalui pemutaran film yang dapat membangkitkan semangat anak. Misalnya film-film bersejarah, film tentang sains, film tentang motivasi berprestasi, dll. Komunikasi sekolah dengan orang tua yaitu adanya Ikatan Orang tua Murid (IOM). Adanya IOM untuk menjalin hubungan yang baik antara sekolah dengan orantua dan masyarakat. Hubungan sekolah dengan IOM ini akan menjadi dukungan moril dan materil untuk menunjang program pengembangan kreativitas anak."

Kreativitas dapat dikembangkan dalam diri siswa melalui proses belajar yang mencakup: (1) pengembangan imajinasi, (2) menghasilkan sesuatu yang orisinil (asli), (3) meningkatkan produktivitas, (4) penyelesaian masalah, dan (5) menghasilkan sesuatu yang bernilai (Sani, 2014:24).

\section{E. Penutup}

\section{Kesimpulan}

Pembelajaran terpadu di SD Pertiwi Kota Bandung dimulai dengan tiga langkah dalam implementasinya, yaitu: (1) tahap persiapan dan perencanaan pembelajaran terpadu, (2) ta- hap pelaksanaan pembelajaran terpadu, dan (3) penilaian pembelajaran terpadu.

Persiapan dan perencanaan pembelajaran terpadu di SD Pertiwi yang dilakukan oleh guru meliputi beberapa hal yaitu: (a) menentukan jenis mata pelajaran dan jenis keterampilan yang dipadukan, (b) memilih kajian materi, standar kompetensi, kompetensi dasar, dan indikator, (c) menentukan sub keterampilan yang dipadukan, (d) merumuskan indikator hasil belajar, dan (e) menentukan langkahlangkah pembelajaran.

Pelaksanaan pembelajaran terpadu di SD Pertiwi menerapkan prinsip-prinsip, yaitu: (a) guru sebagai fasilitator dalam pembelajaran, (b) siswa dibimbing untuk belajar mandiri dan kelompok dalam mengerjakan tugas, dan (c) guru mengakomodatif terhadap kreativitas individu siswa sesuai dengan minat dan bakatnya. Guru dituntut untuk menerapkan metode dan media pembelajaran yang menarik dengan memanfaatkan lingkungan sekolah dan masyarakat. Sedangkan pada tahap evaluasi pembelajaran terpadu guru melakukan evaluasi proses dan evaluasi hasil belajar siswa. 
Pendas : J urnal Ilmiah Pendidikan Dasar, ISSN Cetak : 2477-2143 ISSN Online : 2548-6950

Volume I Nomor 1, Desember 2016

2. Saran

Pembelajaran terpadu di SD Pertiwi sudah diterapkan, namun untuk peningkatan pembelajaran yang berkualitas, ada beberapa saran yang bisa disampaikan diantaranya yaitu: (1) guru masih ada kesulitan dalam menerapkan metode pembelajaran yang interaktif, disarankan agar guru menerapkan metode pembelajaran yang sesuai dengan materi yang akan disampaikan agar siswa senang dan efektif dalam belajarnya, (2) guru disarankan agar dapat menggunakan media pembelajaran yang berfariasi, dan (3) kepala sekolah disarankan dapat mengikutsertakan guru pada kegiatan-kegiatan yang dapat mengembangkan profesionalismenya seperti mengikuti seminar, KKG, MGMP, studi lanjut, dll.

\section{DAFTAR PUSTAKA}

Anderson W, Lorin, dan Krathwol R, David. (2010). Kerangka Landasan Pembelajaran, Pengajaran dan Asesmen. Yoyakarta: Pustaka Pelajar.

Arends, R. (1997). Classroom Instructional Management. New York: The Mc Graw-Hill Company.
Aunurrahman. (2012). Belajar dan Pembelajaran. Bandung: Penerbit Alfabeta.

Beane, J.A. (1995). Introduction: What is a Coherent Curriculum? In J.A Beane (ed). Toward a Coherent Curriculum. (ASCD Yearbook).

Bogdan, R.C. \& Biklen, S.K. (1982). Qualitative Research for Education: on Instruction to Theory and Method. Boston: Allyn Bacon.Inc.

Craft, A. (2003). Membangun Kreativitas Anak. Alih Bahasa: M. Chairul Annam. Jakarta: Inisiasi Press.

Depdikbud. (1996). Pembelajaran Terpadu D-II PGSD dan S2 Pendidikan Dasar. Jakarta: Depdikbud.

Elliot. (1975). Immagination: A Kind of Magical Faculty, Inaugural Lecture, University of Birmingham.

Fogarty, R. (1991). How to Integrated the Curricula. Palatine, Illnois: IRI/Skylight Publishing, Inc.

Hosnan, M. (2014). Pendekatan Saintifik dan Kontekstual dalam Pembelajaran Abad 21. Jakarta: Ghalia Indonesia. 
Pendas : J urnal Ilmiah Pendidikan Dasar, ISSN Cetak : 2477-2143 ISSN Online : 2548-6950

Volume I Nomor 1, Desember 2016

Isjoni. (2007). Integrated Learning. Pekanbaru: Falah Prodution.

Kemendikbud. (2013). Materi Pelatihan Guru Implementasi Kurikulum 2013. Jakarta: BPSDMPKPMP Kemendikbud.

Kunandar. (2014). Penilaian Autentik. Penilaian Hasil Belajar Peserta Didik Berdasarkan Kurikulum 2013. Suatu Pendekatan Praktis. Jakarta: Rajawali Pers.

Majid, Abdul. (2014). Pembelajaran Tematik Terpadu. Bandung: PT Remaja Rosdakarya.

Mulyasa, E. (2014). Pengembangan dan Impelementasi Kurikulum 2013. Bandung: PT Remaja Rosdakarya.

Nazir, Moh. (2011). Metode Penelitian. Jakarta: Ghalia Indonesia.

Munandar, U. C. (1999). Kreativitas dan Keberbakatan, Strategi Mewujudkan Potensi Kreatif \& Bakat. Jakarta: PT. Gramedia Utama.

Nasution, S. (1990). Penelitian Naturalistik-Kualitatif. Bandung: Tarsito.

Prabowo. (2000). Pembelajaran Terpadu di Sekolah Dasar. Makalah.
Disampaikan pada Penyuluhan Guru-Guru SD Wilayah Kecamatan Gayungan.

Puskur. (2007). Pembelajaran Terpadu di Sekolah. Jakarta: Depdikbud.

Samples, B. (2002). Revolusi Belajar Untuk Anak Panduan Belajar Sambil Bermain Untuk Membuka Pikiran Anak-Anak Anda. Alih Bahasa: Rahmani Astuti. Bandung: Kaifa.

Sani A, Ridwan. (2014). Pembelajaran Saintifik untuk Implementasi Kurikulum 2013. Jakarta: Bumi Aksara.

Satori, D \& Komariah, A. (2009). Penelitian Kualitatif. Bandung: Alfabeta.

Saud, S. Udin. \& Resmini, N. (2006). Pembelajaran Terpadu (Bahan Belajar Mandiri). Bandung: UPI Press.

Sugiono. (2016). Metode Penelitian Kuantitatif, Kualitatif dan $R \& D$. Bandung: Alfabeta

Sundayana, Wachyu. (2014). Pembelajaran Berbasis Tema. Panduan Guru dalam Mengembankan Pembelajaran Terpadu. Jakarta: Erlangga. 
Suratno. (2005). Pengembangan Kreativitas Anak Usia Dini. Jakarta: Depdiknas

Susanto, Ahmad. (2015). Teori Belajar dan Pembelajaran di Sekolah Dasar. Jakarta: Kencana.

Suyoto. (2003). Bahan Pelatihan. Tidak dipublikasikan.

Syah, Muhibbin. (2013). Psikologi Belajar. Pengantar Prof. Dr. S.C. Utami Munandar. Jakarta: Rajawali Pers.

Trianto. (2014). Model Pembelajaran Terpadu, Konsep dan Strategi dalam Implementasinya dalam KTSP.Jakarta: Bumi Aksara. 